\title{
In vivo xenoestrogenic actions of cadmium and arsenic in anterior pituitary and uterus
}

\author{
Sonia A Ronchetti ${ }^{1}$, Gisela V Novack ${ }^{1}$, María S Bianchi², Melisa C Crocco ${ }^{1}$, \\ Beatriz H Duvilanski ${ }^{1}$ and Jimena P Cabilla ${ }^{1}$ \\ 'Instituto de Investigaciones Biomédicas (UBA-CONICET), Buenos Aires, Argentina and 'Instituto de Biología y \\ Medicina Experimental (IBYME-CONICET), Buenos Aires, Argentina \\ Correspondence should be addressed to J P Cabilla; Email: jcabilla@ffyb.uba.ar
}

\begin{abstract}
Cadmium (Cd) and arsenic (iAs) are toxic metals ubiquitously present in the environment. Both pollutants exert nonmonotonic dose responses, being mostly cytotoxic at high concentrations but mimicking estrogen (E2) effects at low doses. Xenoestrogenic activity of $\mathrm{Cd}$ and iAs has been demonstrated in different hormone-dependent tumor cell lines; however, their actions in vivo remain largely unknown. Here, we investigated whether in vivo administration of low doses of $\mathrm{Cd}$ and iAs through drinking water would display xenoestrogenic effects in the anterior pituitary gland and uterus of ovariectomized rats. $\mathrm{Cd}(1 \mathrm{ppm})$ and iAs $(0.1 \mathrm{ppm})$ exposure increased the wet weight of anterior pituitary gland and uterus and induced proestrus- and estrus-like vaginal smears. Both metals stimulate cell proliferation of these tissues as they increased the expression of proliferation markers. More importantly, they augmented soluble guanylyl cyclase $\alpha 1$ subunit expression, which has been linked to hormone-dependent tumor progression. Also, $\mathrm{Cd}$ and iAs modified protein levels of full-length estrogen receptor $\alpha$ and its truncated variants in an E2-like manner. Anterior pituitary hormone secretion was differentially affected by both metals. Luteinizing hormone synthesis and release were strongly diminished after $\mathrm{Cd}$ exposure and only mildly reduced by iAs. Both metals were able to increase prolactin synthesis, although only iAs augmented serum prolactin levels. This study shows for the first time that $\mathrm{Cd}$ and iAs exert strong xenoestrogenic effects on anterior pituitary gland at low doses. The differences between $\mathrm{Cd}$ and iAs E2-like behavior indicate that other $\mathrm{Cd}$ - and iAs-specific mechanisms could be involved. Altogether, these results contribute to the knowledge of reproductive disorders associated with $\mathrm{Cd}$ and iAs environmental contamination.

Reproduction (2016) $1521-10$
\end{abstract}

\section{Introduction}

Cadmium (Cd) and arsenic (iAs) are extremely toxic environmental pollutants. In many areas around the world, humans are exposed to high concentrations of these metals. It has been widely described that both acute and chronic exposure to $\mathrm{Cd}$ or iAs are associated with endocrine imbalance and significant reproductive toxicity (ATSDR 1998, 1999).

$\mathrm{Cd}$ is a heavy metal widely dispersed throughout the environment primarily from mining, smelting, and electroplating and is found in consumer products such as batteries, pigments, and plastics (ATSDR 1998). Human Cd intoxication occurs primarily through dietary sources food and water - and cigarette smoke (Koller 1998). This metal has a long biological half-life ( 20 years) and is highly bioaccumulated over time in the blood, kidney, and liver as well as in the reproductive organs (Miler et al. 2010).

iAs is a naturally occurring metalloid with potent toxic and mutagenic effects (Klein et al. 2007). It is ubiquitously present in the environment and is released from both natural and man-made sources (Erbanova et al. 2008). Exposure to iAs from contaminated drinking water is one of the top environmental threats worldwide, based on the potential exposure of people to $\mathrm{iAs}$ and the numerous diseases with which it has been associated (Abernathy et al. 2003). Unlike Cd, iAs undergoes oxidative methylation following uptake, methylated metabolites being more easily excreted from cells (Styblo et al. 2000).

Disruption of the reproductive system of humans and wildlife has been attributed to exposure to environmental contaminants that mimic the effects of steroid hormones (Diamanti-Kandarakis et al. 2009). Moreover, it has been suggested that the high incidence of hormonerelated cancers and diseases in the Western world is also due to the presence of endocrine disruptors (EDs). These compounds are defined as chemical substances that interfere with biosynthesis or activity of several endogenous hormones (McLachlan 2001). Among these, xenoestrogens (XEs) are non-steroidal organic or inorganic chemicals released into the environment from agricultural spraying, industrial activities, urban waste, and consumer products. They mimic the biological 
activity of sex hormones, including androgens and estrogens (Colborn et al. 1993). In the last decade, heavy metals and metalloids such as $\mathrm{Cd}$, iAs, mercury, nickel, lead and zinc have been shown to trigger cell responses normally induced by estrogens, which consequently affect their signaling (Georgescu et al. 2011). Previous reports have shown that $\mathrm{Cd}$ and $\mathrm{i} A \mathrm{~s}$ may exhibit estrogenic mimicry in breast cancer cells by activating the estrogen receptor (ER) (Stoica et al. 2000a,b). Cd and iAs have also been shown to possess potent estrogen-like activity in vivo (Johnson et al. 2003, Jana et al. 2006, Höfer et al. 2009). However, xenoestrogenic effects at low doses of $\mathrm{Cd}$ or iAs in vivo through drinking water, a relevant route of exposure, have been poorly documented.

$17 \beta$-Estradiol (E2) is the major female sex hormone mediating the differentiation, proliferation, development, and homeostasis of female reproductive functions (Morani et al. 2008). E2 stimulatory actions on hormone secretion and cell proliferation are principally mediated by estrogen receptor $\alpha$ (ESR1; ER $\alpha)$. The general structure of ER consists of an N-terminal activator function-1 domain (AF1), followed by the DNA binding domain, a dimerization domain, and a ligand binding/AF-2 domain (Reid et al. 2002). In addition to the full-length $66 \mathrm{kDa}$ ER $(E R \alpha 66)$ isoform, two truncated splice variants of $46 \mathrm{kDa}$ (ER 46 , lacking AF-1 domain) and 36 kDa (ERo36, lacking both AF-1 and AF-2 domains) have been reported (Wang et al. 2005). These splice variants were first detected in the pituitary gland (Mitchner et al. 1998) and then in other tissues including uterus, breast, endometrium, smooth muscle cells, and peripheral blood mononuclear cells (Pendaries et al. 2001, Shupnik 2002, Taylor et al. 2010).

E2 control of cell proliferation involves the regulation of target genes including cyclins, cyclin-dependent kinases (CDKs), proto-oncogenes, and negative cell cycle regulators. E2 induces expression of cyclins (A, $\mathrm{D}$, and $\mathrm{E}$ ) and other proteins such as the proliferating cell nuclear antigen (PCNA), which are involved in the control of cell cycle progression from $G_{0 / 1}$ to $S$ and $M$ (Matsuo et al. 1999, Butt et al. 2005).

E2-induced cell proliferation is also directly associated with upregulation of alpha 1 subunit of the soluble guanylyl cyclase (GUCY1A3). GUCY1A3, together with (GUCY1B3), forms Soluble guanylyl cyclase (sGC), the major intracellular receptor for nitric oxide (NO). $\mathrm{NO}$ binding to sGC activates this enzyme to catalyze the formation of cGMP from GTP (Krumenacker et al. 2004). Previous studies from our group demonstrated that E2 chronic and acute administration increases Gucy1a3 mRNA and protein expression and decreases Gucy $1 b 3$ levels in the anterior pituitary gland both in vivo and in vitro (Cabilla etal. 2006, 2009, 2011). Furthermore, Cai and coworkers have shown that androgendriven GUCY1A3 upregulation correlates with cell proliferation in advanced prostate cancer, suggesting that GUCY1A3 could be an important mediator of procarcinogenic effects of androgens (Cai et al. 2007).
E2 are major regulators of anterior pituitary physiology, eliciting a plethora of processes including stimulation of lactotroph proliferation and upregulation of prolactin (PRL) gene expression, synthesis, and release (Freeman et al. 2000). Cd and iAs, at micromolar doses, have been shown to inhibit anterior pituitary secretion through feedback mechanisms or by directly affecting anterior pituitary cells (Lafuente \& Esquifino 1999, Poliandri et al. 2003, 2006, Sarkar et al. 2003, Miler et al. 2010, Ronchetti 2014). However, we previously showed that $\mathrm{Cd}$ at nanomolar concentrations exerts E2-like activities on these cells in culture (Ronchetti et al. 2013). However, to date, iAs-mediated effects on the anterior pituitary gland have not been studied.

Considering previous knowledge, the aim of this study is to investigate whether in vivo administration of low doses of $\mathrm{Cd}$ and iAs through drinking water would display xenoestrogenic effects on the anterior pituitary gland. We also performed uterotrophic assays including histological analysis and E2-responsive gene expressions to further complete the landscape of E2-like effects of $\mathrm{Cd}$ and iAs.

\section{Materials and methods}

\section{Ethics statement}

All experimental procedures were approved by the Committee on Ethics of the School of Medicine (University of Buenos Aires, Res. (CD) No. 2831/10) and were carried out in compliance with the guidelines of the Institutional Committee for Care and Use of Laboratory Animals (CICUAL, School of Medicine, University of Buenos Aires) and the NIH Guide for the Care and Use of Laboratory Animals.

\section{Drugs and reagents}

Cadmium chloride $\left(\mathrm{CdCl}_{2} \cdot 2 \frac{1}{2} \mathrm{H}_{2} \mathrm{O}\right)$ was purchased from Mallinckrodt Chemical Works (St. Louis, MO, USA). Sodium (meta) arsenite $\left(\mathrm{NaAsO}_{2}\right)$ was purchased from Sigma-Aldrich. Protease inhibitor cocktail, ACTB ( $\beta$-actin), soluble guanylyl cyclase $\alpha 1$ (GUCY1A3), and $\beta 1$ (GUCY1B3) antibodies were obtained from Sigma-Aldrich. Ketamine and xylazine were purchased from König (Buenos Aires, Argentina). Ketofen was obtained from Vetanco S.A. (Buenos Aires, Argentina). Proliferating cell nuclear antigen (PCNA), cyclin D3 (CCND3), and $E R \alpha$ antibodies were purchased from Santa Cruz Biotechnology. Anti-recombinant rat PRL and anti-rLH-11 antisera were provided by $\mathrm{Dr}$ A $\mathrm{F}$ Parlow (National Hormone and Pituitary Program, Torrance, CA, USA).

\section{Animals and treatments}

Adult female Wistar rats (180-200g) were ovariectomized (OVX) under ketamine and xylazine anesthesia. After surgery, animals received an s.c. injection of $1 \%$ ketroprofen and were exposed to $\mathrm{Cd}$ or iAs treatment through drinking water for a month after a recovery period of 1 week. Animals were kept 
under controlled conditions of light (12 h light:12 h darkness cycle) and temperature $\left(21-24^{\circ} \mathrm{C}\right)$ and received standard laboratory chow (Cooperación, Buenos Aires, Argentina) and tap water ad libitum. Neither iAs nor $\mathrm{Cd}$ levels were measured in the standard laboratory chow. Tap water $(<10$ ppb iAs, www. nutrired.org/agua/page/4) was filtered by PSA Senior System (PSA, Buenos Aires, Argentina), which retains most of the heavy metals including $\mathrm{Cd}$.

Toxicant concentrations were selected after running a pilot experiment ranging from 0.01 to $5 \mathrm{ppm}$. Based on an uterotrophic assay, the minimum concentration showing significant xenoestrogenic effects was chosen for each metal. After surgery, animals ( $N=6$ per cage) were randomly divided into four groups: control, Cd, iAs, and E2 (positive control). The control group drank filtered tap water without any metal. Treated groups were exposed to $1 \mathrm{ppm} \mathrm{CdCl}_{2} .2 \frac{1}{2} \mathrm{H}_{2} \mathrm{O}$ or $0.1 \mathrm{ppm}$ $\mathrm{NaAsO}_{2}$ corresponding to an average intake of $51 \mu \mathrm{g} / \mathrm{kg} /$ day and $6 \mu \mathrm{g} / \mathrm{kg} /$ day respectively. The positive control group was conformed by animals implanted s.c. with a silastic capsule containing $500 \mu \mathrm{g} 17 \beta$-estradiol with free access to filtered tap water without any metal.

Samples of vaginal smears were collected daily. In order to avoid iAs oxidation, drinking water iAs solution was freshly prepared everyday. Body weight and water consumption were monitored periodically with no differences between control and treated groups. On day 30, rats were killed by decapitation. Anterior pituitary glands and uteri were removed, weighed, and stored in liquid nitrogen for further procedures.

\section{Histological analysis}

Uteri were fixed in Bouin solution for $20 \mathrm{~h}$ at room temperature (RT). Tissues were cut into $5 \mu \mathrm{m}$-thick sections and stained with hematoxylin-eosin (HE) for morphological analysis.

\section{Immunohistochemistry}

Histological uterus sections obtained from each animal and fixed in Bouin solution were paraffin-embedded. For deparaffinization, sections were placed at $60^{\circ} \mathrm{C}$ overnight and then treated for $5 \mathrm{~min}$ with xylene at RT. Rehydration was performed through incubation in a decreasing series of alcohols (ethanol $100,96,90,70$, and $40 \%$ ) and a second incubation in distilled water for $5 \mathrm{~min}$. Antigen exposure followed immersion of the tissues in $10 \mathrm{mM}$ citrate buffer. Samples were heated twice for $3 \mathrm{~min}$ in a previously humidified microwave oven. Endogenous peroxidases were inactivated in a $3 \% \mathrm{H}_{2} \mathrm{O}_{2}$-ethanol $70 \%$ solution for $10 \mathrm{~min}$ in darkness at $25^{\circ} \mathrm{C}$. Uterus sections were incubated for $90 \mathrm{~min}$ in a blocking solution (2\% BSA-PBS, $10 \%$ goat serum) after three washes with $0.1 \%$ PBS-Triton $\mathrm{pH}$ 7. Samples were incubated with anti-ER $\alpha$ antibody $(1: 100)$ diluted in $0.1 \%$ PBS-Triton $/ 1 \%$ goat serum solution at $4{ }^{\circ} \mathrm{C}$ in a humidified chamber overnight. After washing with $0.1 \%$ PBSTriton $\mathrm{pH} 7.4$, sections were incubated with anti-rabbit IgGhorseradish peroxidase $(1: 400)$ diluted in $0.1 \%$ PBS-Triton $/ 1 \%$ goat serum. Immunoreaction product was visualized by Kit DAB (Vector Laboratories, Burlingame, CA, USA). Reaction was stopped with distilled water. After dehydration, samples were treated with xylene for $5 \mathrm{~min}$ and mounted with DPX.

\section{Preparation of tissue homogenates for immunoblot analysis}

Pituitaries were individually sonicated in lysis buffer $(50 \mathrm{mM}$ HEPES, pH 7.4, $150 \mathrm{mM} \mathrm{NaCl}, 1 \mathrm{mM}$ EDTA, and 0.1\% SDS) containing protease inhibitor cocktail (1:500). Uteri were cut into small fragments and homogenized in lysis buffer $(20 \mathrm{mM}$ Tris, pH 7.4, 1 mM EDTA, and 0.1\% Tween 20) containing protease inhibitor cocktail (1:500) in an IKA Ultra Turrax T18115 VAC (Cole Palmer, Vernon Hills, IL, USA). Homogenates were centrifuged for $20 \mathrm{~min}$ at $10,000 \mathrm{~g}\left(4^{\circ} \mathrm{C}\right)$ and post-mitochondrial fractions were used for the immunoblot analysis.

\section{Protein measurement}

The protein content of supernatants was measured by Bradford reagent (Bio-Rad), using bovine serum-albumin as a standard.

\section{Immunoblot analysis}

About $40-80 \mu \mathrm{g}$ of total protein from each sample were boiled for $5 \mathrm{~min}$ in Laemmli sample buffer and fractionated on $15 \%$ SDS-PAGE. Resolved proteins were transferred to polyvinylidene difluoride membranes and blocked for $24 \mathrm{~h}$ at $4^{\circ} \mathrm{C}$ in blocking buffer ( $5 \%$ nonfat dry milk in $1 \% \mathrm{~T}$-TBS). Then, membranes were co-incubated overnight at $4{ }^{\circ} \mathrm{C}$ with primary antibodies: anti-CCND3 (sc-6283, 1:500), anti-PCNA (sc-56, 1:1000), anti-ER $\alpha$ (sc-542, 1:500), anti-PRL (Millipore, AB960, 1:25000), anti-LH (anti-rbetaLH-IC-2, 1:500), anti-GUCY1A3 (G4280, 1:1500), anti-GUCY1B3 (G4405, 1:500), and anti-ACTB (A2066, 1:1000), respectively, in blocking buffer. Blots were washed and incubated for $1 \mathrm{~h}$ at RT with secondary antibodies (1:2000), which were used depending on the primary antibodies: goat anti-rabbit IgG-horseradish peroxidase (111-035-003; Jackson, West Grove, PA, USA) and goat anti-mouse IgG-horseradish peroxidase (P0447; SigmaAldrich). Membranes were revealed using ECL detection kit (Kalium, Buenos Aires, Argentina).

\section{Analysis of immunoblot data}

Intensity of immunoblot signals was determined by digital image analysis using Gel Pro Analyzer software for Windows. For statistical comparison of results from different blots, levels were normalized to the value of the ACTB-immunoreactive band in each lane.

\section{Hormone determination}

PRL and luteinizing hormone (LH) were measured by a double-antibody radioimmunoassay (RIA) (Quinteros et al. 2007) using reagents provided by Dr A F Parlow (National Hormone and Pituitary Program, Torrance, CA, USA). Recombinant PRL (NIDDK-rPRL-RP-3) and recombinant LH (LHRP-3) were used as reference preparations. NIDDK-anti-rPRL-S-9 and antirLH-11 were used as antisera. Sensitivity of the assay was $0.1 \mathrm{ng} / \mathrm{mL}$. Intra- and inter-assay coefficient of variation was under $10 \%$. To prevent inter-assay variations, all samples were measured in the same assay. 


\section{Statistical analysis}

Results were expressed as mean \pm S.E.M. and evaluated by Student's t-test or one-way analysis of variance (ANOVA) followed by Dunnett's test. Differences between groups were considered significant if $P<0.05$. Results were confirmed by at least three independent experiments.

\section{Results}

\section{$C d$ and iAs exposure-induced changes in vaginal cytology of ovariectomized (OVX) rats}

Estrous cycle analysis is a well-known method to determine xenoestrogenicity of environmental pollutants (Laws et al. 2000). Samples of vaginal smears from each experimental group were collected daily in the last 2 weeks of treatment. As expected, OVX control rats remained in diestrus because of estrogen withdrawal, whereas E2-treated rats (positive control) showed typical vaginal cytology of estrus. Smears corresponding to proestrus and estrus were found in both $\mathrm{Cd}$ - and iAs-exposed animals with a concomitant decrease in the relative frequency of diestrus (Fig. 1).

\section{Cd and iAs exposure increased anterior pituitary and uterine wet weights}

E2 regulates development and growth of many E2-responsive tissues. Anterior pituitary gland and sections of $3 \mathrm{~cm}$ from the uterus were carefully removed and weighed after killing animals. Similar to observations in E2-treated rats, exposure to $\mathrm{Cd}$ and iAs significantly increased wet weight of anterior pituitary gland by a 1.2 - and 1.9-fold increase respectively ( $\mathrm{mg}$ tissue/g body weight; control: $0.037 \pm 0.002 ; \mathrm{Cd}: 0.045 \pm 0.003 *$; iAs: $0.07 \pm 0.01^{* *} ; \mathrm{E} 2: 0.137 \pm 0.008^{* * *}$, ANOVA followed by Dunnett's test, ${ }^{*} P<0.05,{ }^{* *} P<0.01,{ }^{* * *} P<0.001$ vs control). Also, uterine wet weight showed a 1.9- and 2.5-fold increase respectively (mg tissue/g body weight;

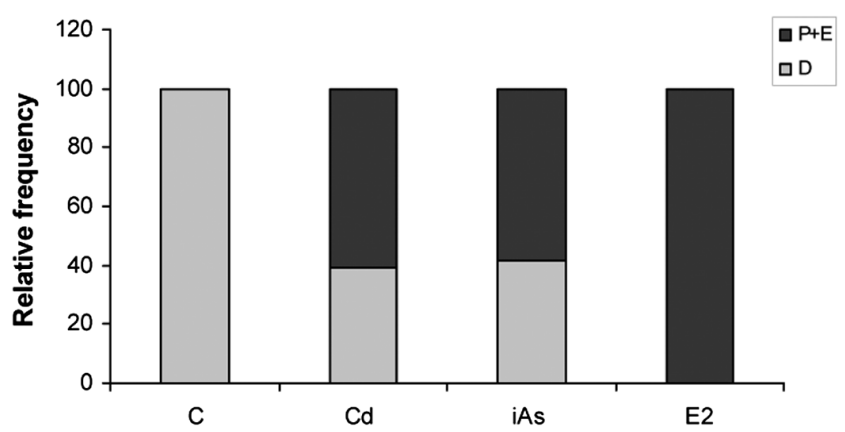

Figure $1 \mathrm{Cd}$ and iAs exposure caused vaginal cytology of proestrus and estrus-like stages in ovariectomized rats. Samples of vaginal smears were collected daily in the last $2 \mathrm{wk}$ of treatment. Bars represent the number of animals on proestrus + estrus $(P+E)$ or diestrus $(D)$ relative to the total number of animals per treatment $(n=6)$. control: $0.15 \pm 0.01 ; C d: 0.29 \pm 0.01 *$, iAs: $0.38 \pm 0.06^{* *}$; E2: $0.72 \pm 0.09 * *$, ANOVA followed by Dunnett's test, ${ }^{*} P<0.05,{ }^{* *} P<0.01 \mathrm{vs}$ control). Altogether, these results suggest that the pollutants exert a trophic effect on these E2-responsive tissues.

\section{Cd and iAs exposure stimulated cell proliferation marker expression in the anterior pituitary gland}

Considering that $\mathrm{Cd}$ and iAs exposure increased the wet weight of the anterior pituitary gland, we determined whether this effect was a consequence of cell proliferation. We evaluated the expression of two classic cell proliferation markers involved in cell cycle progression such as proliferating cell nuclear antigen (PCNA) and cyclin D3 (CCND3) by western blot.

Exposure to both $\mathrm{Cd}$ and iAs significantly augmented protein expression levels of both markers to a similar extent to that observed in E2-treated rats (Fig. 2A and B).

\section{Cd and iAs exposure upregulated soluble guanylyl cyclase alpha 1 (GUCY1A3) protein levels but not $\beta 1$ (GUCY1B3) subunit expression in the anterior pituitary gland}

Previously, we showed that E2 differentially regulates GUCY1A3 and GUCY1B3 subunit expressions in anterior pituitary gland by increasing GUCY1A3 levels, whereas GUCY1B3 expression decreased or remained unchanged (Cabilla et al. 2006, 2009). To further investigate whether $\mathrm{Cd}$ and iAs were able to mimic E2 effect on these subunits, protein levels were measured. As previously reported, E2 significantly augmented GUCY1A3 expression in the anterior pituitary gland but did not modify GUCY1B3 levels. Accordingly, Cd and iAs exposure mimicked E2 effects on sGC subunits to a similar extent, thus confirming that these metals reproduced the hormone's effects not only through classic E2-responsive genes but also by affecting the expression of other proteins not classically related to E2 proliferative signaling (Fig. 3).

\section{Cd and iAs exposure modified estrogen receptor (ER) levels in the anterior pituitary gland}

Previous evidence indicates that E2 regulates the synthesis of its own full-length receptor (ERo66) and truncated variants ER 36 and ER 46 (Mitchner 1998, Shupnik 2002). To examine the xenoestrogenic actions of $\mathrm{Cd}$ and iAs on ER $\alpha$ expression, protein levels were evaluated by western blot. Both $\mathrm{Cd}$ and iAs reproduced E2 effect by significantly augmenting ERo46 expression. iAs exposure induced a significant increase in ER 666 , whereas Cd, such as E2, did not modify its expression (Fig. 4). In all cases, the protein band corresponding to ER $\alpha 36$ was undetected; therefore, it was excluded from further analysis. 
A
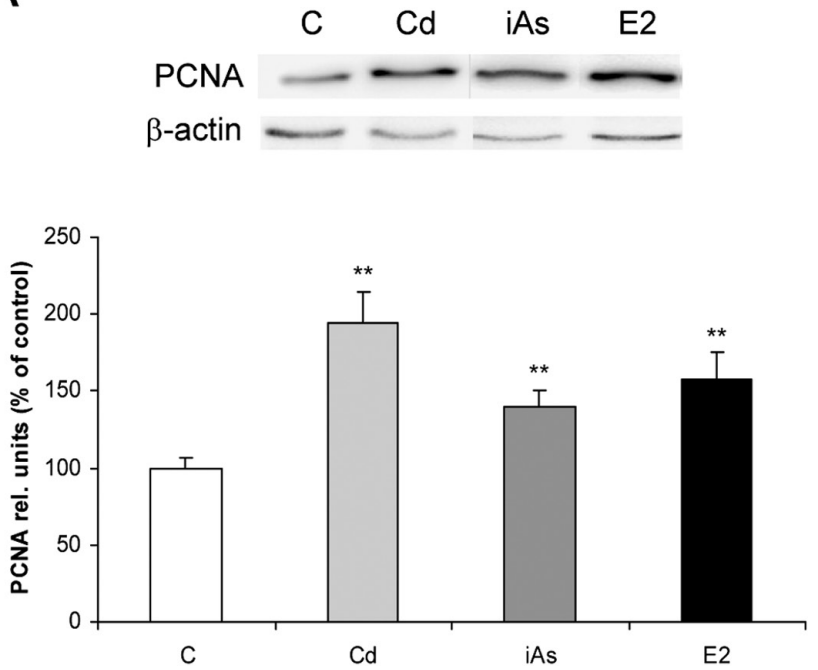

B
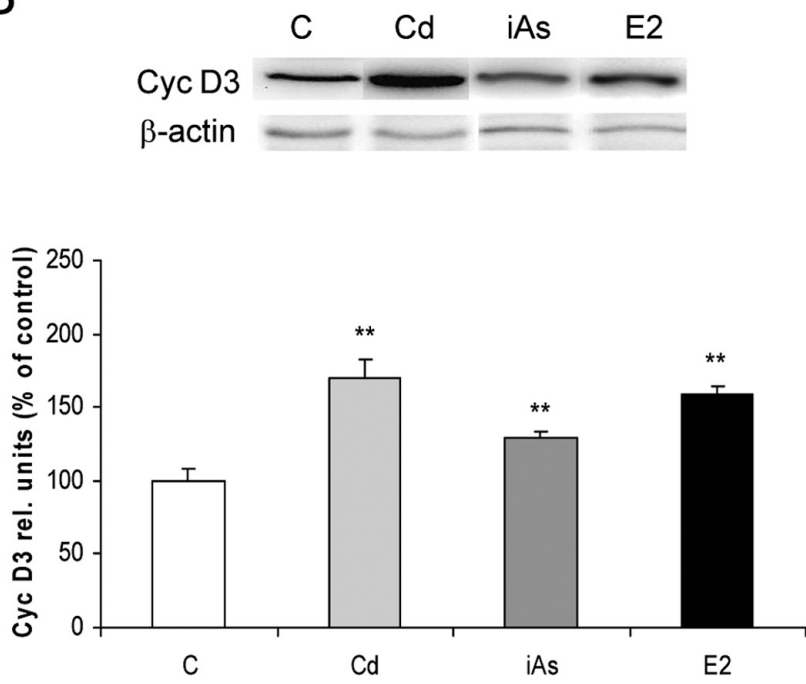

Figure $2 \mathrm{Cd}$ and iAs exposure stimulated cell proliferation marker expression in the anterior pituitary gland. (A) Proliferating cellular nuclear antigen (PCNA) and (B) cyclin D3 (CCND3; Cyc D3) protein expression was determined by western blot. Bars represent mean \pm S.E. of relative units corresponding to protein densitometric values relative to ACTB ( $\beta$-actin) $(n=6)$ expressed as percentage of control. ANOVA followed by Dunnett's test, ${ }^{* *} P<0.01$.

\section{Cd and iAs exposure differentially affected prolactin (PRL) and luteinizing hormone (LH) secretion}

Anterior pituitary hormones such as PRL and LH play a key role in the reproductive physiology control, their secretion tightly regulated by E2. To investigate whether $\mathrm{Cd}$ and iAs mimic E2 action on PRL and LH secretion in the anterior pituitary gland, protein expression and serum levels of these hormones were measured by western blot and RIA respectively.

As a consequence of gonadal steroid withdrawal after ovariectomy, control OVX rats exhibited significantly lower PRL and higher LH levels compared with

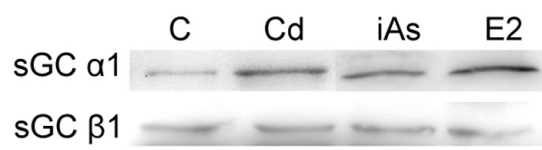

$\beta$ - actin

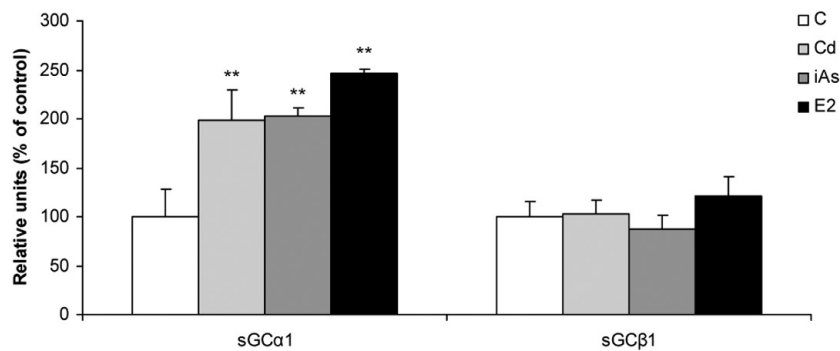

Figure $3 \mathrm{Cd}$ and iAs exposure increased soluble guanylyl cyclase alpha 1 (GUCY1A3; sGC $\alpha 1$ ) subunit levels but not beta 1 (GUCY1B3; sGC $\beta 1$ ) expression in the anterior pituitary gland. sGC $\alpha 1$ and sGC $\beta 1$ protein levels were evaluated by western blot. Bars represent mean \pm S.E.M. of relative units corresponding to protein densitometric values normalized to ACTB ( $\beta$-actin) $(n=6)$ expressed as percentage of control. ANOVA followed by Dunnett's test, ${ }^{* *} P<0.01$.

intact random rats (PRL; intact: $14.1 \pm 2.9 \mathrm{ng} / \mathrm{mL}$; OVX: $4.29 \pm 0.78 \mathrm{ng} / \mathrm{mL}^{*}$; LH intact: $0.74 \pm 0.12 \mathrm{ng} / \mathrm{mL}$; OVX: $22.7 \pm 2.1 \mathrm{ng} / \mathrm{mL}^{* * *}, \quad N=6$, Student's $t$-test, ${ }^{*} P<0.05$, $* * * P<0.001)$. Exposure to $\mathrm{Cd}$ or iAs significantly increased PRL expression, suggesting that these metals can stimulate its synthesis. Tallying with iAs-induced PRL protein increase, iAs exposure augmented PRL release; however unexpectedly, $\mathrm{Cd}$ did not significantly modify it (Table 1).

Regarding LH secretion, only Cd was able to decrease both protein expression and serum levels, as iAs exposure did not significantly modify these parameters (Table 1 ).

In sum, these results show that $\mathrm{Cd}$ and iAs exert xenoestrogenic effects in the anterior pituitary gland by stimulating E2-regulated genes involved in cell proliferation, E2 canonic and noncanonic signaling, and by affecting hormone secretion.

\section{Evaluation of Cd and iAs estrogenicity in uterus}

Next, to further characterize the estrogenic potency of these pollutants, we determined $\mathrm{Cd}$ - and iAs-driven estrogenic responses by studying histological and molecular parameters in the uterus.

\section{Morphological analysis}

Uterus histological examination revealed that $\mathrm{Cd}$ and iAs exposure increased the number and size of endometrial glands and height of luminal and glandular epithelium. $\mathrm{Cd}$ exposure also increased the number of invaginations. According to previous reports (Johnson et al. 2003, Höfer et al. 2009), chronic E2 treatment caused endometrial hyperplasia and hypertrophy (Fig. 5). 

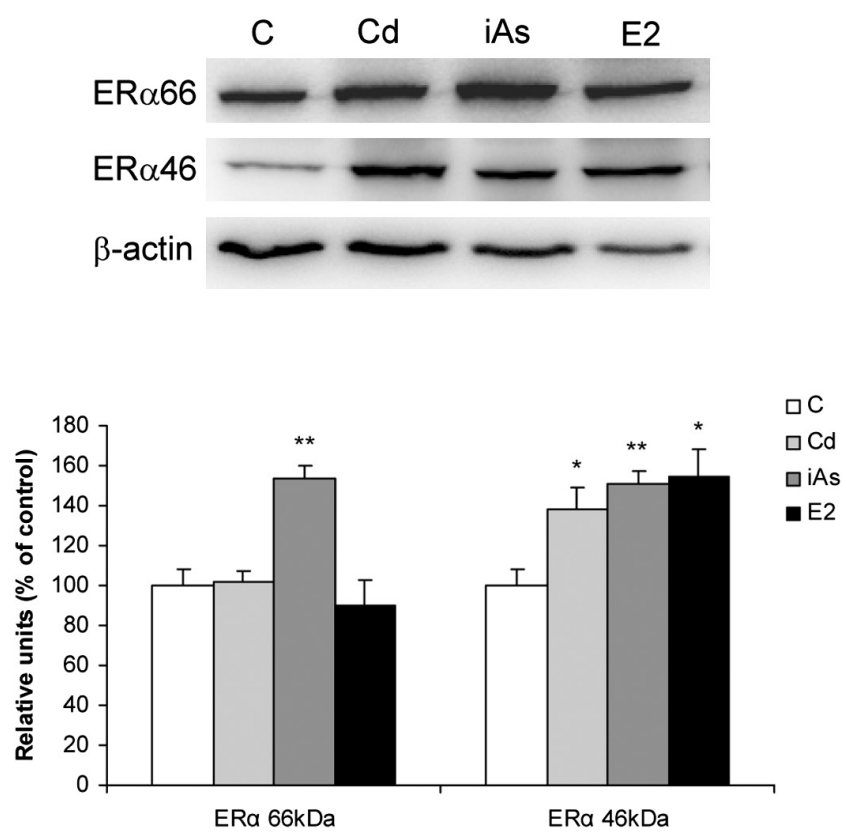

Figure $4 \mathrm{Cd}$ and $\mathrm{iAs}$ exposure modified the expression of estrogen receptor $\alpha$ (ESR1; ER $\alpha 66)$ and its truncated variant ER $\alpha 46$ in the anterior pituitary gland. ER $\alpha 66$ and $E R \alpha 46$ expressions were determined by western blot. Bars represent mean \pm S.E.M. of relative units corresponding to $\mathrm{ER} \alpha 66$ and $\mathrm{ER} \alpha 46$ densitometric values relative to ACTB ( $\beta$-actin) $(n=6)$ expressed as percentage of control. ANOVA followed by Dunnett's test, ${ }^{*} P<0.05,{ }^{* *} P<0.01$.

\section{ERo expression}

It has been widely reported that development and maintenance of the uterine endometrium are principally mediated by E2 through activation of ER $\alpha$. Here, we studied ER $\alpha$ expression in the uterus by immunohistochemistry. Uteri from control rats showed weak staining localized in the nucleus of luminal and glandular epithelial as well as stromal cells. $\mathrm{Cd}$ and iAs exposure produced augmented immunoreactive nuclear ER $\alpha$ staining in luminal and glandular epithelial cells. Particularly, stromal cells showed the strongest ER $\alpha$ immunostaining intensity (Fig. 6A).

Table $1 \mathrm{Cd}$ and iAs exposure differentially affected PRL and LH synthesis and release. Protein levels of intrapituitary PRL and LH were determined by western blot. Trunk blood was collected after killing animals to evaluate hormone content. Serum levels of PRL and $\mathrm{LH}$ were measured by radioimmunoassay (RIA).

\begin{tabular}{|c|c|c|c|c|}
\hline & \multicolumn{2}{|c|}{$\begin{array}{c}\text { Serum hormone levels } \\
(\mathrm{ng} / \mathrm{mL})\end{array}$} & \multicolumn{2}{|c|}{$\begin{array}{l}\text { Intrapituitary hormone } \\
\text { protein levels }^{\mathrm{a}}\end{array}$} \\
\hline & PRL & $\mathrm{LH}$ & PRL & $\mathrm{LH}$ \\
\hline Control & $4.29 \pm 0.78$ & $22.7 \pm 2.1$ & $100 \pm 15$ & $100 \pm 17$ \\
\hline $\mathrm{Cd}$ & $3.8 \pm 1.8$ & $11.5 \pm 2.4^{* *}$ & $153 \pm 7^{* *}$ & $35.6 \pm 9.9^{* *}$ \\
\hline iAs & $6.69 \pm 0.79 *$ & $16.1 \pm 0.6$ & $165 \pm 12^{*}$ & $96.6 \pm 13.3$ \\
\hline E2 & $455.9 \pm 65.1^{* * *}$ & $0.75 \pm 0.12^{* *}$ & $220.2 \pm 30.2^{* * *}$ & $10.9 \pm 2.2^{* *}$ \\
\hline
\end{tabular}

Values represent mean \pm S.E.M. from each experimental group $(n=6)$. aRelative units as \% of controls. ANOVA followed by Dunnett's test, ${ }^{*} P<0.05,{ }^{* *} P<0.01,{ }^{* * *} P<0.001$.

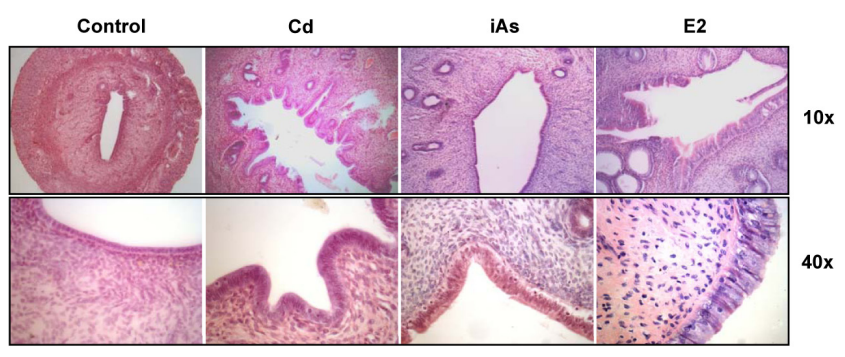

Figure $5 \mathrm{Cd}$ and iAs exposure induced E2-like morphological changes in the uterus. Uteri were removed after killing and stained under hematoxylin-eosin (HE) technique for histological analysis. General view of uteri and endometrial glands (10x). Epithelium and stromal cells detail (40x).

In order to further validate the effects of these pollutants on full-length and variants of ER $\alpha$ expression, protein levels were evaluated by western blot. In concordance with results for anterior pituitary gland, exposure to $\mathrm{Cd}$ and iAs resulted in an increased expression of ERo46. Similar to observations in the anterior pituitary gland (Fig. 4), ERo66 expression was differentially affected by these pollutants being significantly upregulated by iAs but unchanged after Cd exposure (Fig. 6B).

\section{Cell proliferation markers}

To confirm Cd and iAs proliferative effects - evidenced by increased uterine wet weight and augmented cell number qualitatively observed by histological studies - PCNA and CCND3 expressions were evaluated. As we expected, $\mathrm{Cd}$ and iAs exposure, such as E2 treatment, significantly augmented protein levels of both markers (Fig. 7A and B).

A
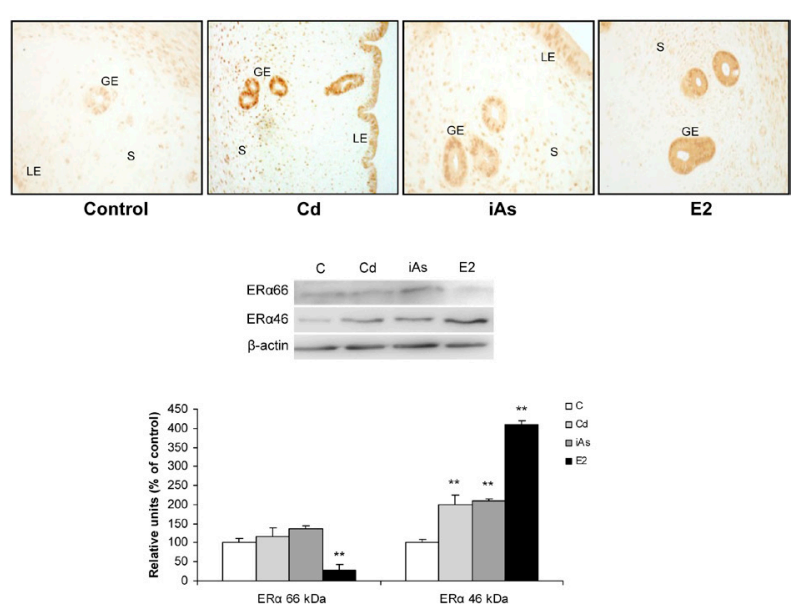

Figure $6 \mathrm{Cd}$ and iAs exposure augmented ESR1 (ESR1 (ER $\alpha)$ expression in the uterus. (A) Uteri were removed after killing and processed for immunohistochemical staining for ER $\alpha$ expression. LE, luminal epithelium; GE, glandular epithelium, S, stroma (40x). (B) ER $\alpha 66$ and $E R \alpha 46$ protein expressions were evaluated by western blot. Bars represent mean \pm S.E.M. of relative units corresponding to protein densitometric values relative to ACTB ( $\beta$-actin) $(n=6)$ expressed as percentage of control. ANOVA followed by Dunnett's test, ${ }^{* *} P<0.01$. 

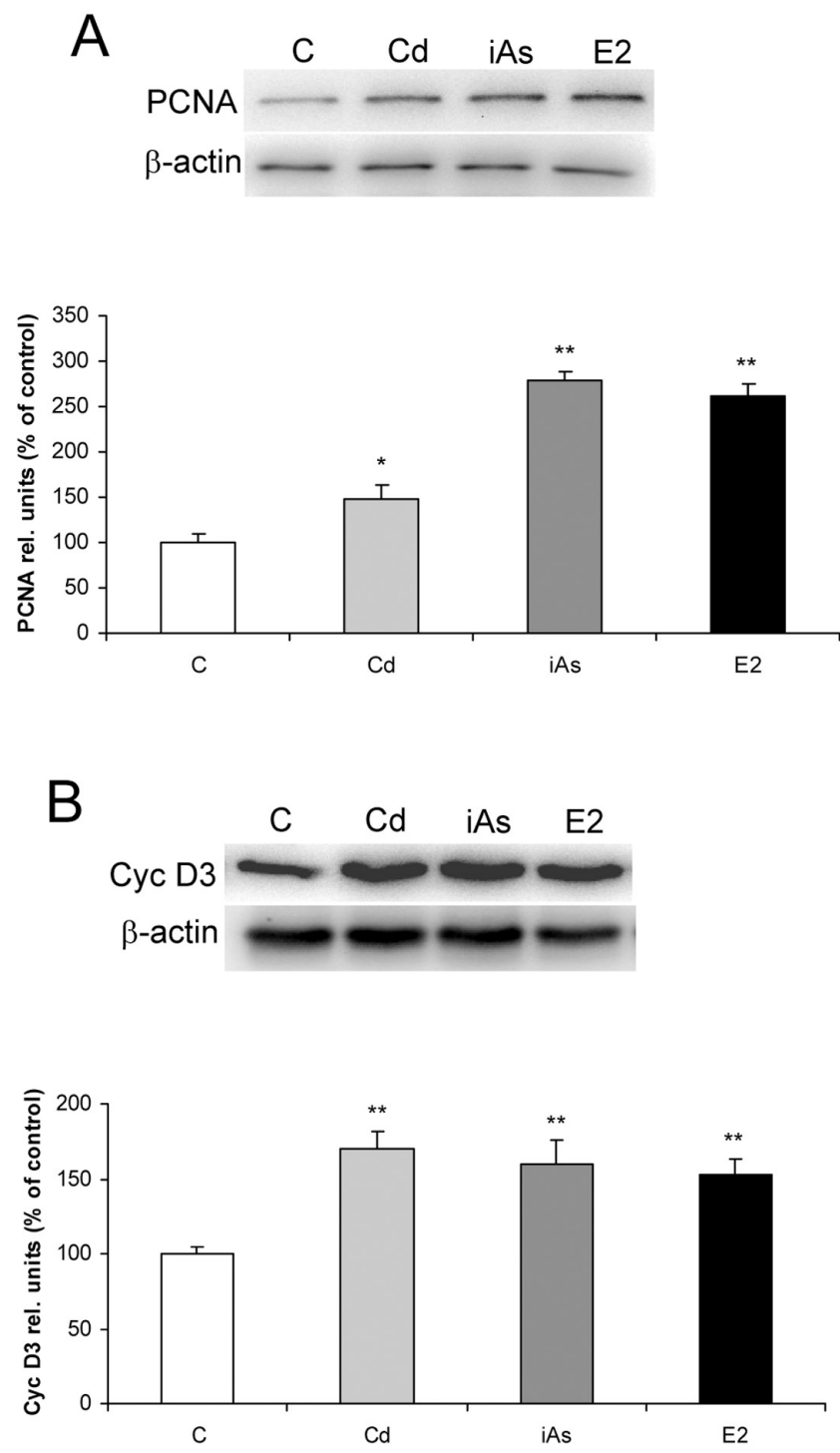

Figure $7 \mathrm{Cd}$ and $\mathrm{iAs}$ exposure increased cell proliferation markers in the uterus. (A) PCNA, (B) CCND3 (Cyc D3) protein levels were evaluated by western blot. Bars represent mean \pm S.E.M. of relative units corresponding to protein densitometric values relative to ACTB ( $\beta$-actin) $(n=6)$ expressed as percentage of control. ANOVA followed by Dunnett's test, $* P<0.05, * * P<0.01$.

Finally, we analyzed the expression of GUCY1A3 and GUCY1B3 as an estrogen-responsive gene. Results showed that exposure to either metal significantly augmented GUCY1A3 expression and did not modify GUCY1B3 to a similar extent, as did E2 treatment (Fig. 8).

To sum up, similar to observations of the anterior pituitary, these results showed that $\mathrm{Cd}$ as well as iAs display uterotrophic E2-like effects evidenced by morphological and molecular changes.

\section{Discussion}

In this study, we investigated the xenoestrogenic effects of low doses of $\mathrm{Cd}$ and iAs exposure through drinking water in the pituitary gland and uterus.
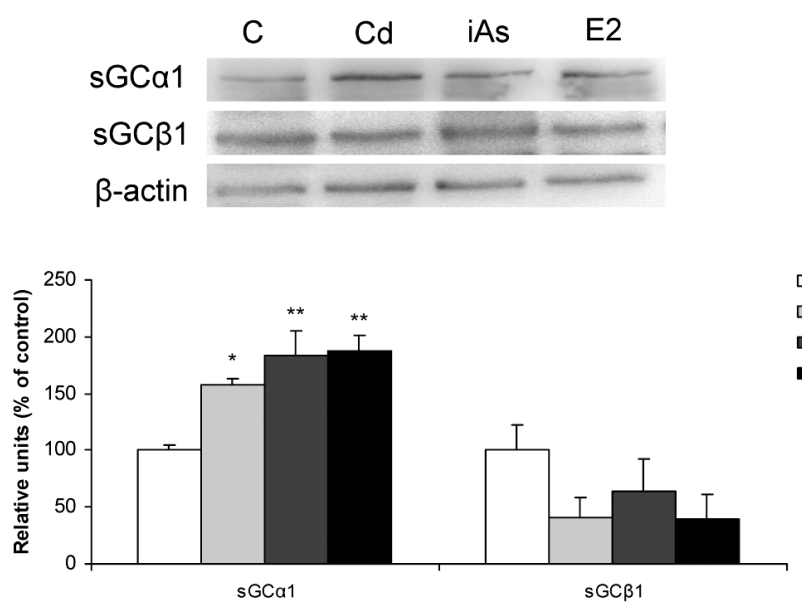

Figure $8 \mathrm{Cd}$ and iAs exposure augmented soluble guanylyl cyclase alpha 1 (GUCY1A3; sGC $\alpha 1$ ) subunit levels but not beta 1 (GUCY1B3; sGC $\beta 1$ ) expression in the uterus. sGC $\alpha 1$ and sGC $\beta 1$ protein levels were evaluated by western blot. Bars represent mean \pm S.E.M. of relative units corresponding to protein densitometric values normalized to ACTB ( $\beta$-actin) $(n=6)$ expressed as percentage of control. ANOVA followed by Dunnett's test, $* P<0.05$, ${ }^{* *} P<0.01$.

Similar to many endocrine disruptors, $\mathrm{Cd}$ and iAs display non-monotonic actions depending on their concentrations. At high (micromolar) levels, these pollutants exert cytotoxic effects and induce oxidative stress leading to cell death (Poliandri et al. 2003, 2004, Ronchetti 2014), whereas at low (nanomolar) levels, mimic E2 actions by promoting cell proliferation and affecting hormone secretion (Johnson et al. 2003, Stoica et al. 2000a,b, Ronchetti et al. 2013, Ronchetti 2014).

This is the first report on E2-like effects of $\mathrm{Cd}$ and iAs on the pituitary gland in vivo. Here, we demonstrated that both toxicants stimulate cell proliferation, modify pituitary hormone secretion, and up-regulate E2-responsive genes. Our present data tally with previous results from our laboratory demonstrating that nanomolar $\mathrm{Cd}$ concentrations exert estrogenic activity in the anterior pituitary cells in culture and in lactosomatotroph GH3 cell line (Ronchetti et al. 2013). Regarding iAs, its xenoestrogenic effects on this gland have not been reported yet.

iAs effects are specific to species and tissue due to differential accumulation, methylation, and excretion. In rats, this metalloid binds to blood proteins higher than other mammalian species, which decreases both bioavailability and accumulation in other tissues. Comparatively, mouse, rabbit, and human, among other species, are more vulnerable to adverse iAs effects (Vahter 1999, Naranmandura et al. 2007). However, Cd toxicity does not substantially differ among species, being easily accumulated in all tissues (Bhattacharyya et al. 2000).

To date, in vivo studies of E2-like effects of $\mathrm{Cd}$ and $\mathrm{iAs}$ have been performed mainly by administration through i.p. or i.v. injections (Waalkes et al. 2000, Johnson et al. 2003, Höfer et al. 2009). However, we chose oral exposition to these pollutants through drinking water as it 
reproduces more plausible conditions of toxicant exposition and normal gastrointestinal absorption, which is by-passed by any non-oral route.

Here, we showed that exposure to iAs, at a dose as low as $0.1 \mathrm{ppm}$, displayed effects comparable to $1 \mathrm{ppm}$ $\mathrm{Cd}$ regarding macroscopic indices of estrogenicity such as estrous cycle and wet weight of E2-responsive tissues. This finding could be due to differential absorption in the gastrointestinal tract, being about $95 \%$ for iAs and only $5 \%$ for Cd (ATDSR 1998, 1999).

By using the uterus, a well-known target of E2 and E2-like compounds (Rice et al. 2003, Kanno et al. $2003 a, b)$, we confirmed that $\mathrm{Cd}$ as well as iAs exerted xenoestrogenic activities by increasing uterine wet weight and inducing molecular and histological changes similar to those observed following E2 stimulation.

Here, we showed that both, $\mathrm{Cd}$ and iAs, were able to increase classical proliferation markers such as CCND3 and PCNA in the anterior pituitary gland and uterus. More importantly, both were able to augment GUCY1A3 expression and did not modify GUCY1B3 levels. These results concord with previous evidence obtained after E2 chronic and acute administration in the anterior pituitary gland (Cabilla et al. 2004). Regarding uterus, to date, E2 effects on GUCY1A3 expression were associated only with sGC enzymatic activity. In this sense, Murad et al. reported acute E2-triggered Gucy1a3 mRNA and protein down-regulation and decreased sGC activity (Krumenacker et al. 2001). Contrary to this evidence, we found that long-term E2 or E2-like compound exposure resulted in significant GUCY1A3 upregulation without affecting GUCY1B3 expression.

Considering that both $\mathrm{sGC}$ subunits are required in a 1:1 stoichiometry to shield enzymatic activity, this $\mathrm{Cd}$ - and iAs-driven imbalance in their expression is likely related to other sGC functions independent of its cGMP-producing activity. In this sense, GUCY1A3 has been elegantly linked to cell proliferation and tumor progression in other hormone-responsive tissues (Cai et al. 2008, 2012). Our observations open a new field as GUCY1A3 might be an important mediator of the procarcinogenic effects exerted by any E2-like compound in hormone-dependent tissues, a line currently under investigation.

Anterior pituitary expresses full-length ER $\alpha$ and two truncated variants, ER $\alpha 36$ and ER $\alpha 46$, which play a key role in E2-regulated feedback in this gland (Mitchner et al. 1998). In uterus, many ERo-splicing variants have been reported (Varayoud et al. 2005), including the aforementioned truncated variants. Noticeably, only iAs was able to augment full-length ER $\alpha$ expression in both tissues, whereas $\mathrm{Cd}$ did not modify it. In this sense, it seems that iAs cannot fully modulate E2 feedback loop on its receptor, which indicates that iAs and $\mathrm{Cd}$ might differ in their respective estrogenic potencies or in the activation of alternative E2-related regulatory mechanisms. E2 treatment decreased full-length $E R \alpha$ in the uterus. This observation tallies with previous reports on the long-term E2 administration to OVX rats (Mohamed \& Abdel-Rahman 2000).

In uterus, our studies showed that exposure to both toxicants induced strong $\mathrm{ER} \alpha$ immunoreactive staining localized in luminal and glandular epithelial as well as in stromal cells. Similar results were observed in mouse uterus after repeated i.v. $0.5 \mathrm{mg} / \mathrm{kg}$ iAs injections (Waalkes et al. 2000). Molecular analysis revealed that the rise in $E R \alpha$ expression is mainly due to an increase in ERo46 levels. Concordantly, $\mathrm{Cd}$ and iAs exposure also increased ER $\alpha 46$ protein levels in the anterior pituitary gland in a manner similar to E2. These observations could be due to negative regulation in response to long-term E2 or E2-like compound stimulation. Several endocrine disruptors are able to activate $E R \alpha$; however, the effects on ER $\alpha$ variant expression remain largely unknown. Recently, the phytoestrogen genistein was reported to increase ER 446 expression in brain cortex from OVX rats (Morán et al. 2013).

Regarding hormone secretion, our findings showed that $\mathrm{Cd}$ as well as iAs mimicked E2 by increasing PRL synthesis, whereas unexpectedly, only iAs was able to stimulate PRL release. To date, little is known about lowdose $\mathrm{Cd}$ and iAs effects on hormone pituitary secretion. The present data partially contrast with previous in vitro results by showing that $\mathrm{Cd}$ at nanomolar concentrations for $48 \mathrm{~h}$ increases synthesis and release of PRL in primary anterior pituitary cultures, probably due to differences in the two experimental designs.

Both toxicants exerted differential effects on LH secretion. $\mathrm{Cd}$ reduced both intrapituitary $\mathrm{LH}$ protein levels and release, possibly by reproducing hypothalamic E2 regulatory actions on GNRH release. Also, we cannot rule out that under subchronic in vivo exposure, $\mathrm{LH}$ and PRL release could be affected by other Cd-triggered actions independent of its xenoestrogenic activity, a possibility that needs to be investigated.

However, iAs produced a slight but non-significant $\mathrm{LH}$ decrease. At the hypothalamic level, lower iAs accumulation due to the brain-blood barrier and enhanced iAs excretion via methylated metabolites (Sanchez-Peña et al. 2010) could explain this mild iAs xenoestrogenic action on $\mathrm{LH}$.

Considering the central role of anterior pituitary hormone in reproduction and the ubiquitous nature of these toxicants, more detailed understanding of the endocrine effects of $\mathrm{Cd}$ and iAs exposure carry great relevance. In this direction, we have provided the first in vivo approach to $\mathrm{Cd}$ and iAs xenoestrogenic activity in the anterior pituitary gland and broadened knowledge of their proliferative actions in the uterus.

This information is essential for knowledge of exposurerelated reproductive disruptions as well as preneoplastic and neoplastic pathologies associated with these pollutants, thereby contributing to better understanding of the etiology of conditions that represent grave risks to human and animal health. 


\section{Declaration of interest}

The authors declare that there is no conflict of interest that would prejudice the impartiality of this scientific work.

\section{Funding}

This work was supported by grants from the Argentine National Agency for the Promotion of Science and Technology (ANPCyT) (PICT 2010-1668 to BHD and PICT 2013-1324 to JPC) and the Argentine National Council for Science and Technology (CONICET) (PIP 2013-1077 to BHD and PIP 2012-1038 to JPC).

\section{Acknowledgments}

The authors are very grateful to Lic. Mercedes Imsen and Lic. Alfonsina Lizárraga for their invaluable assistance and care of laboratory animals and Lic. Cristina Deparci for her excellent collaboration with histological techniques.

\section{References}

Abernathy CO, Thomas DJ \& Calderon RL 2003 Health effects and risk assessment of arsenic. Journal of Nutrition 133 1536S-1538S.

ATSDR. Toxicological Profile for Cadmium. Atlanta, GA, USA: Agency for Toxic Substances and Disease Register, US Department of Health \& Human Services, 1998.

ATSDR. Toxicological Profile for Arsenic. Atlanta, GA, USA: Agency for Toxic Substances and Disease Register, US Department of Health \& Human Services, 1999.

Bhattacharyya MH, Wilson AK, Rajan SS \& Jonah M 2000 Biochemical pathway in cadmium toxicity. In Molecular Biology and Toxicology of Metals, pp 1-74. Eds RK Zalup \& J Koropatnick. London, UK: Taylor \& Francis.

Butt AJ, McNeil CM, Musgrove EA \& Sutherland RL 2005 Downstream targets of growth factor and oestrogen signalling and endocrine resistance: the potential roles of $\mathrm{C}-\mathrm{Myc}$, cyclin D1 and cyclin E. Endocrine Related Cancer 12 47-59. (doi:10.1677/erc.1.00993)

Cabilla JP, Díaz MC, Lasaga M \& Duvilanski BH 2004 17 $\beta$-estradiol modifies the expression of nitric oxide receptor soluble guanylyl cyclase in anterior pituitary gland. 12th International Congress of Endocrinology, Lisbon, Portugal. Proceedings P513.

Cabilla JP, Díaz Mdel C, Machiavelli LI, Poliandri AH, Quinteros FA, Lasaga M \& Duvilanski BH 200617 beta-estradiol modifies nitric oxidesensitive guanylyl cyclase expression and down-regulates its activity in rat anterior pituitary gland. Endocrinology 147 4311-4318.

Cabilla JP, Ronchetti SA, Nudler SI, Miler EA, Quinteros FA \& Duvilanski BH 2009 Nitric oxide sensitive-guanylyl cyclase subunit expression changes during estrous cycle in anterior pituitary glands. American Journal of Physiology. Endocrinology and Metabolism 296 E731-E737. (doi:10.1152/ajpendo.90795.2008)

Cabilla JP, Nudler SI, Ronchetti SA, Quinteros FA, Lasaga M \& Duvilanski BH 2011 Nitric oxide-sensitive guanylyl cyclase is differentially regulated by nuclear and non-nuclear estrogen pathways in anterior pituitary gland. PLOS ONE 6 e29402.

Cai C, Chen SY, Zheng Z, Omwancha J, Lin MF, Balk SP \& Shemshedini L 2007 Androgen regulation of soluble guanylyl cyclase alpha1 mediates prostate cancer cell proliferation. Oncogene 226 1606-1615.

Cai C, Hsieh CL, Gao S, Kannan A, Bhansali M, Govardhan K, Dutta R \& Shemshedini L 2012 Soluble guanylyl cyclase $\alpha 1$ and p53 cytoplasmic sequestration and down-regulation in prostate cancer. Molecular Endocrinology 26 292-307. (doi:10.1210/me.2010-0394)

Colborn T, vom Saal FS \& Soto AM 1993 Developmental effects of endocrine-disrupting chemicals in wildlife and humans. Environmental Health Perspectives 101 378-384. (doi:10.1289/ehp.93101378)
Diamanti-Kandarakis E, Bourguignon JP, Giudice LC, Hauser R, Prins GS, Soto AM, Zoeller RT \& Gore AC 2009 Endocrine-disrupting chemicals: an Endocrine Society scientific statement. Endocrine Reviews 30 293-342. (doi:10.1210/er.2009-0002)

Erbanova L, Novak M, Fottova D \& Dousova B 2008 Export of arsenic from forested catchments under easing atmospheric pollution. Environmental Science \& Technology 42 7187-7192.

Freeman ME, Kanyicska B, Lerant A \& Nagy G 2000 Prolactin: structure, function, and regulation of secretion. Physiological Reviews $801523-631$.

Georgescu B, Georgescu C, Dărăban S, Bouaru A \& Paşcalău S 2011 Heavy metals acting as endocrine disrupters. Scientific Papers: Animal Science and Biotechnologies 44 89-93.

Höfer N, Diel P, Wittsiepe J, Wilhelm M \& Degen GH 2009 Dose- and route-dependent hormonal activity of the metalloestrogen cadmium in the rat uterus. Toxicology Letters 191 123-131. (doi:10.1016/j. toxlet.2009.08.014)

Jana K, Jana S \& Samanta PK 2006 Effects of chronic exposure to sodium arsenite on hypothalamo-pituitary-testicular activities in adult rats: possible an estrogenic mode of action. Reproductive Biology and Endocrinology 16 4-9.

Johnson MD, Kenney N, Stoica A, Hilakivi-Clarke L, Singh B, Chepko G, Clarke R, Sholler PF, Lirio AA, Foss C et al. 2003 Cadmium mimics the in vivo effects of estrogen in the uterus and mammary gland. Nature Medicine 9 1081-1084. (doi:10.1038/nm902)

Kanno J, Onyon L, Peddada S, Ashby J, Jacob E \& Owens W 2003a The OECD program to validate the rat uterotrophic bioassay. Phase 2: doseresponse studies. Environmental Health Perspectives 111 1530-1549.

Kanno J, Onyon L, Peddada S, Ashby J, Jacob E \& Owens W 2003b The OECD program to validate the rat uterotrophic bioassay. Phase 2: coded single-dose studies. Environmental Health Perspectives 111 1550-1558.

Klein CB, Leszczynska J, Hickey C \& Rossman TG 2007 Further evidence against a direct genotoxic mode of action for arsenic-induced cancer. Toxicology and Applied Pharmacology 222 289-297. (doi:10.1016/j. taap.2006.12.033)

Koller LD 1998 Cadmium. In Immunotoxicology of Environmental and Occupational Metals, pp 41-61. Eds JT Zelikoff \& PT Thomas. London, UK: Taylor \& Francis.

Krumenacker JS, Hyder SM \& Murad F 2001 Estradiol rapidly inhibits soluble guanylyl cyclase expression in rat uterus. PNAS 98 717-722. (doi:10.1073/pnas.98.2.717)

Krumenacker JS, Hanafy KA \& Murad F 2004 Regulation of nitric oxide and soluble guanylyl cyclase. Brain Research Bulletin 62 505-515. (doi:10.1016/S0361-9230(03)00102-3)

Lafuente A \& Esquifino Al 1999 Cadmium effects on hypothalamic activity and pituitary hormone secretion in the male. Toxicology Letters $\mathbf{1 1 0}$ 209-218. (doi:10.1016/S0378-4274(99)00159-9)

Laws SC, Carey SA, Ferrell JM, Bodman GJ \& Cooper RL 2000 Estrogenic activity of octylphenol, nonylphenol, bisphenol A and methoxychlor in rats. Toxicological Sciences 54 154-167. (doi:10.1093/toxsci/54.1.154)

Martin MB, Reiter R, Pham T, Avellanet YR, Camara J, Lahm M, Pentecost E, Pratap K, Gilmore BA, Divekar S et al. 2003 Estrogen-like activity of metals in MCF-7 breast cancer cells. Endocrinology 144 2425-2436. (doi:10.1210/en.2002-221054)

Matsuo H, Kurachi O, Shimomura Y, Samoto T \& Maruo T 1999 Molecular bases for the actions of ovarian sex steroids in the regulation of proliferation and apoptosis of human uterine leiomyoma. Oncology 57 49-58. (doi:10.1159/000055275)

McLachlan JA 2001 Environmental signaling: what embryos and evolution teach us about endocrine disrupting chemicals. Endocrine Reviews 22 319-341. (doi:10.1210/edrv.22.3.0432)

Miler EA, Nudler SI, Quinteros FA, Cabilla JP, Ronchetti SA \& Duvilanski BH 2010 Cadmium induced-oxidative stress in pituitary gland is reversed by removing the contamination source. Human and Experimental Toxicology 29 873-880. (doi:10.1177/0960327110362703)

Mitchner NA, Garlick C \& Ben-Jonathan N 1998 Cellular distribution and gene regulation of estrogen receptors $\alpha$ and $\beta$ in the rat pituitary gland. Endocrinology 139 3976-3983.

Mohamed MK \& Abdel-Rahman AA 2000 Effect of long-term ovariectomy and estrogen replacement on the expression of estrogen receptor gene in female rats. European Journal of Endocrinology 142 307-314. (doi:10.1530/eje.0.1420307) 
Morán J, Garrido P, Alonso A, Cabello E \& Gonzalez C 2013 17 $\beta$-estradiol and genistein acute treatments improve come cerebral cortex homeostasis aspects deteriorated by aging in female rats. Experimental Gerontology 48 414-421. (doi:10.1016/j.exger.2013.02.010)

Morani A, Warner M \& Gustafsson JA 2008 Biological functions and clinical implications of oestrogen receptors $\alpha$ and $\beta$ in epithelial tissues. Journal of Internal Medicine 264 128-142. (doi:10.1111/jim.2008.264. issue-2)

Naranmandura H, Suzuki N, Iwata K, Hirano S \& Suzuki KT 2007 Arsenic metabolism and thioarsenicals in hamsters and rats. Chemical Research in Toxicology 20 616-624. (doi:10.1021/tx700038x)

Pendaries C, Darblade B, Rochaix P, Krust A, Chambon P, Korach KS, Bayard F \& Arnal JF 2001 The AF-1 activation-function of ERalpha may be dispensable to mediate the effect of estradiol on endothelial $\mathrm{NO}$ production in mice. PNAS 99 2205-2210.

Poliandri AH, Cabilla JP, Velardez MO, Bodo CC \& Duvilanski BH 2003 Cadmium induces apoptosis in anterior pituitary cells that can be reversed by treatment with antioxidants. Toxicology and Applied Pharmacology 190 17-24. (doi:10.1016/S0041-008X(03)00191-1)

Poliandri AH, Velardez MO, Cabilla JP, Bodo CC, Machiavelli LI, Quinteros AF \& Duvilanski BH 2004 Nitric oxide protects anterior pituitary cells from cadmium-induced apoptosis. Free Radical Biology and Medicine 37 1463-1471.

Poliandri AH, Esquifino AI, Cano P, Jiménez V, Lafuente A, Cardinali DP \& Duvilanski BH 2006 In vivo protective effect of melatonin on cadmium-induced changes in redox balance and gene expression in rat hypothalamus and anterior pituitary. Journal of Pineal Research $\mathbf{4 1}$ 238-246. (doi:10.1111/jpi.2006.41.issue-3)

Quinteros FA, Poliandri AH, Machiavelli LI, Cabilla JP \& Duvilanski BH 2007 In vivo and in vitro effects of chromium VI on anterior pituitary hormone release and cell viability. Toxicology Applied Pharmacology 218 79-87. (doi:10.1016/j.taap.2006.10.017)

Reid G, Denger S, Kos M \& Gannon F 2002 Human estrogen receptoralpha: regulation by synthesis, modification and degradation. Cellular and Molecular Life Sciences 59 821-831. (doi:10.1007/s00018-0028470-2)

Rice C, Birnbaum LS, Cogliano J, Mahaffey K, Needham L, Rogan WJ \& vom Saal FS 2003 Exposure assessment for endocrine disruptors: some considerations in the design of studies. Environmental Health Perspectives 111 1683-90. (doi:10.1289/ehp.5798)

Ronchetti SA Effects of arsenic on anterior pituitary gland. Mechanisms of action. PhD Thesis 2014. University of Buenos Aires.

Ronchetti SA, Miler EA, Duvilanski BH \& Cabilla JP 2013 Cadmium mimics estrogen-driven cell proliferation and prolactin secretion from anterior pituitary cells. PLOS ONE 8 e81101.

Sánchez-Peña LC, Petrosyan P, Morales M, González NB, Gutiérrez-Ospina G, Del Razo LM \& Gonsebatt ME 2010
Arsenic species, AS3MT amount, and AS3MT gene expression in different brain regions of mouse exposed to arsenite. Environmental Research 110 428-434. (doi:10.1016/j.envres.2010.01.007)

Sarkar M, Chaudhuri GR, Chattopadhyay A \& Biswas NM 2003 Effect of sodium arsenite on spermatogenesis, plasma gonadotrophins and testosterone in rats. Asian Journal of Andrology 5 27-31.

Shupnik MA 2002 Oestrogen receptors, receptor variants and oestrogen actions in the hypothalamic-pituitary axis. Journal of Neuroendocrinology 14 85-94. (doi:10.1046/j.0007-1331.2001.00744.x)

Stoica A, Katzenellenbogen BS \& Martin MB 2000a Activation of estrogen receptor-alpha by the heavy metal cadmium. Molecular Endocrinology 14 545-553.

Stoica A, Pentecost E \& Martin MB 2000b Effects of arsenite on estrogen receptor-alpha expression and activity in MCF-7 breast cancer cells. Endocrinology 141 3595-3602.

Styblo M, Del Razo LM, Vega L, Germolec DR, LeCluyse EL, Hamilton GA, Reed W, Wang C, Cullen WR \& Thomas DJ 2000 Comparative toxicity of trivalent and pentavalent inorganic and methylated arsenicals in rat and human cells. Archives of Toxicology 74 289-299. (doi:10.1007/ s002040000134)

Taylor SE, Martin-Hirsch PL \& Martin FL 2010 Oestrogen receptor splice variants in the pathogenesis of disease. Cancer Letters 288 133-148. (doi:10.1016/j.canlet.2009.06.017)

Vahter M 1999 Methylation of inorganic arsenic in different mammalian species and population groups. Science Progress 82 69-88.

Varayoud J, Ramos JG, Monje L, Bosquiazzo V, Muñoz-de-Toro M \& Luque EH 2005 The estrogen receptor alpha sigma3 mRNA splicing variant is differentially regulated by estrogen and progesterone in the rat uterus. Journal of Endocrinology 186 51-60. (doi:10.1677) joe.1.06099)

Waalkes MP, Keefer LK \& Diwan BA 2000 Induction of proliferative lesions of the uterus, testes, and liver in swiss mice given repeated injections of sodium arsenate: possible estrogenic mode of action. Toxicology and Applied Pharmacology 166 24-35. (doi:10.1006/taap.2000.8963)

Wang Z, Zhang X, Shen P, Loggie BW, Chang Y \& Deuel TF 2005 Identification, cloning, and expression of human estrogen receptoralpha36, a novel variant of human estrogen receptor-alpha66. Biochemical and Biophysical Research Communications 336 1023-1027.

Received 4 March 2016

First decision 29 March 2016

Revised manuscript received 30 March 2016

Accepted 7 April 2016 